\title{
Characterization of ESBL-Producing Enterobacteria from Fruit Bats in an Unprotected Area of Makokou, Gabon
}

Pierre Philippe Mbehang Nguema ${ }^{1,2,3,+}$, Richard Onanga ${ }^{2, *} \mathbb{C}$, Guy Roger Ndong Atome ${ }^{4}$, Jean Constant Obague Mbeang ${ }^{1}$, Arsène Mabika Mabika ${ }^{2}$, Moussa Yaro ${ }^{4}$, Manon Lounnas ${ }^{5,6} \mathbb{D}$, Yann Dumont ${ }^{5,6}$, Zaidi Fatma Zohra ${ }^{6,7}$, Sylvain Godreuil ${ }^{5,6, t}$ and François Bretagnolle ${ }^{3, \dagger}$

1 Laboratoire de Microbiologie, Institut de Recherche en Ecologie Tropicale (IRET), (Centre National de recherche Scientifique et Technologique/CENAREST), Libreville B.P. 13354, Gabon;

mbehangphilippe@gmail.com (P.P.M.N.); obaguejean@gmail.com (J.C.O.M.)

2 Laboratoire de Bactériologie de Recherche, Unité de recherche et d'Analyses Médicales (URAM), Centre Interdisciplinaire de Recherches Médicales de Franceville (CIRMF), Franceville B.P. 679, Gabon; raaghmabika@gmail.com

3 UMR CNRS/uB 6282 Biogéosciences, Université de Bourgogne, 6 bd Gabriel, 21000 Dijon, France; francois.bretagnolle@u-bourgogne.fr

4 Département de Chimie, Faculté des Sciences, Université des Sciences et Technique de Masuku (USTM), Franceville B.P. 943, Gabon; saint.claire112014@gmail.com (G.R.N.A.); lozo.10.yaro@gmail.com (M.Y.)

5 Laboratoire de Bactériologie, Centre Hospitalier Universitaire de Montpellier, Université de Montpellier, 34295 Montpellier, France; manon.lounnas@gmail.com (M.L.); y-dumont@chu-montpellier.fr (Y.D.); s-godreuil@chu-montpellier.fr (S.G.)

6 UMR MIVEGEC IRD-CNRS-Université de Montpellier, IRD, 911 Avenue Agropolis, 34394 Montpellier, France; fatmazohrazaidi89@gmail.com

7 Laboratoire d'Ecologie Microbienne, FSNV, Université de Bejaia, Bejaia 06000, Algerie

* Correspondence: richard.onanga@cirmf.ga; Tel.: +241-0621-1384

$\dagger$ These authors contributed equally to this work.

Received: 3 December 2019; Accepted: 11 January 2020; Published: 19 January 2020

Abstract: In Gabon, terrestrial mammals of protected areas have been identified as a possible source of antibiotic-resistant bacteria. Some studies on antibiotic resistance in bats have already been carried out. The main goal of our study was to detect extended-spectrum beta-lactamases (ESBLs) that are produced by enterobacteria from bats in the Makokou region in Gabon. Sixty-eight fecal samples were obtained from 68 bats caught in the forests located $1 \mathrm{~km}$ from the little town of Makokou. After culture and isolation, 66 Gram-negative bacterial colonies were obtained. The double-disk diffusion test confirmed the presence of ESBLs in six (20.69\%) Escherichia coli isolates, four $(13.79 \%)$ Klebsiella pneumoniae isolates, and one (3.45\%) Enterobacter cloacae isolate. The analysis based on the nucleotide sequences of the ESBL resistance genes showed that all cefotaximase-Munichs (CTX-Ms) were CTX-M-15 and that all sulfhydryl variables (SHVs) were SHV-11: 41.67\% CTX-M-15-producing E. coli, 16.67\% CTX-M-15+SHV-11-producing E. coli, 8.33\% CTX-M-15-producing K. pneumoniae, 25\% CTX-M-15+SHV-11-producing K. pneumoniae, and 8.33\% CTX-M-15-produced E. cloacae. This study shows for the first time the presence of multiresistant ESBL-producing enterobacteria in fruit bats in Makokou.

Keywords: bats; Gram-negative bacteria; ESBL; multiresistance; reservoir 


\section{Introduction}

Bats are an important, widespread, and abundant taxon of mammals with over 1300 described species [1]. These species are considered as the reservoir of many viruses that periodically spread in human populations during disease outbreaks and whose dynamics need to be fully understood [2]. Bats have also been recognized as a potential reservoir of bacterial pathogens, although little is known concerning bat microbiota [2-4]. Among bats, the Pteropodidae family (large oldworld and mostly frugivorous bats) are suspected to play an important role in the dynamic of zoonosis. Many species are colonials with individuals roosting in close physical proximity that favors multiple interactions and opportunities for intraspecific pathogen transmission [4-7]. Most of the species have a wide-ranging distribution, and many urban colonies of several thousands of individuals are established in African or Asian countries, increasing the opportunities for bat-human pathogen transmission.

The existence of antibiotic multi-resistant (AMR) enterobacteria that have been recurrently documented in wildlife in recent years provide important insights into the potential role of wildlife as reservoirs of resistant bacteria. AMR enterobacteria are also pertinent markers to understand the dynamics of zoonosis and the complex transmission routes among wildlife and humans [8]. Many ways of wildlife AMR bacteria acquisition have been documented, such as contamination from human or domestic animal effluent, wastewater, and even contaminated food remains [8]. However, the possible existence of AMR enterobacteria has been poorly investigated in large fruit bats, although it could provide key information on bat-human transmission.

In several studies, antibiotic-resistant bacteria have been described in bat isolates, suggesting the possibility of these mammals being one of their environmental reservoirs [4,6,9-15]. In a survey of wild and captive grey-headed flying foxes (Pteropus poliocephalus), McDougall et al. detected the presence of resistance to several antibiotic families in 5.3\% of wild flying foxes from different Australian colonies [6]. This study provided evidence of both transfer from humans to bats and from the environmental resistome to bats. A wide-ranging study that investigated the presence of antimicrobial resistance in wildlife and humans in the urban environment of Nairobi (Kenya) [16] found that fruit bats and some bird species were more likely to carry AMR E. coli than other taxonomic wildlife groups. This study has shown that urban environments play an important role in the dynamics of wildlife-human interactions and increase the frequency of wildlife-to-human transmission. In contrast, in a recent study, Brazilian fruit bats showed a low occurrence of resistance in their enterobacterial microbiota due to the well-preserved environment where the animal was captured [1]. However, the role of fruit bats in wildlife-human interactions is still poorly documented and needs to be more deeply investigated, particularly in the context of anthropogenic environments.

Beta-lactamases are enzymes that provide resistance to the beta-lactam family of antibiotics in Gram-negative bacteria (GNB) such as enterobacteria. These enzymes are classified into classes A-D [17]. Among these enzymes, those belonging to molecular class A extended-spectrum beta-lactamases (ESBLs) are active against expanded-spectrum cephalosporins and monobactams (Aztreonam) [18]. The introduction of extended-spectrum cephalosporin in clinical practice has caused the emergence and worldwide spreading of ESBLs in the Enterobacteriaceae such as Klebsiella pneumoniae and Escherichia coli $[18,19]$. The worldwide presence of EBSLs is at the origin of therapeutic failure when treating bacterial infections $[19,20]$. ESBL types temoneira (TEM), sulfhydryl variable (SHV), and cefotaximase-Munich (CTX-M) are the most common ESBLs found in humans, livestock, and wildlife [6]. The global spread of ESBL-producing Enterobacteriaceae, particularly CTX-M-15, creates serious therapeutic challenges [10,21-32].

In Gabon, CTX-M-15 has only been identified in ESBL-producing Enterobacteriaceae isolates from patients in the Albert Schweitzer Hospital in Lambaréné [31] and in poultry [32], but not in wildlife. Although previous studies on antibiotic resistance in Gabon have already described some phenotypes and resistance genes in wild terrestrial mammals $[21,29,30]$, nothing is known about their dissemination in the environment. We hypothesized that bats could participate in the dissemination of antibiotic resistance in wildlife [14]. 
This study aimed to provide additional knowledge about the spread of ESBL-producing Enterobacteriaceae isolates from bats of the Pteropodidae family in Makokou (central Gabon).

\section{Materials and Methods}

\subsection{Research License}

The research licence for this study was obtained from the Scientific Commission on Research Authorisations of the National Centre of Scientific and Technological Research (CENAREST) (permit no. AR0033/17/MESRSFC/CENAREST/CG/CST/CSAR, dated 4 July 2017).

\subsection{Study Area}

The collection of bat fecal samples was carried out in an unprotected forest area of Makokou in Ogooué Ivindo province (located in the northeast region of Gabon) over two periods. The first capture was made at the entrance of the caves on the outskirts of the city over 10 days in May 2017. The second capture occurred near the fruit trees behind the town houses over 6 days in October 2017.

\subsection{Collection of Fecal Samples}

To capture the bats, a mist net $\left(3000 \times 2000 \mathrm{~mm}, \mathrm{ECOTONE}^{\circledR}\right.$, France) was installed in the early evening in the narrow forests behind the human dwellings between 18:00 and 06:00. The nets were continuously monitored, and bats were immediately removed and placed in cloth bags. In the laboratory, fecal samples were collected from 68 bats. A cotton swab was rotated inside the bat rectum and was immediately discharged into $5 \mathrm{~mL}$ of sterile water. One millilitre of liquid sample was inoculated into BacT/Alert blood culture media (bioMérieux, Auvergne-Rhône-Alpes, France) according to a previously established protocol [30]. After incubation, enterobacteria present in the medium produced $\mathrm{CO}_{2}$ during their growth phase. $\mathrm{CO}_{2}$ product induces a decrease in $\mathrm{pH}$ of the culture medium. This change in $\mathrm{pH}$ caused the bottom of the bottle to change from blue to yellow (positive samples). The bottles containing positive samples, the bottoms of which were yellow, were kept at $4{ }^{\circ} \mathrm{C}$ pending further analysis.

\subsection{Culture, Isolation and Identification of Colonies}

In the bacteriology laboratory of the International Centre for Medical Research of Franceville (CIRMF), $50 \mu \mathrm{L}$ of bacterial solution of each Bact/Alert vial was streaked on MacConkey agar (MCA) (bioMérieux, France) supplemented with $4 \mu \mathrm{g} / \mathrm{mL}$ cefotaxime and incubated at $37^{\circ} \mathrm{C}$ for $24 \mathrm{~h}$. After incubation, each colony, differentiated by structure and color, was picked and transferred by the same means and incubated in the same conditions. The purified colonies were subjected to biochemical identification by the VITEK ${ }^{\circledR} 2$ Compact 15 (bioMérieux, Marcy l'étoile, France).

\subsection{Antibiotic Susceptibility Testing}

ESBL production was phenotypically confirmed on Mueller-Hinton (MH) agar when the difference in the inhibition diameter zone from one of the cephalosporins (cefotaxime or ceftazidime) was alone and in combination with a disk containing clavulanic acid of $\geq 5 \mathrm{~mm}$. ESBL production was confirmed by the double-disk synergy test. Antibiotic resistance was assessed by the disk-diffusion test method [33] on MH agar (BioMérieux) and the clinical breakpoints recommended by the European Committee on Antimicrobial Susceptibility Testing (EUCAST) guidelines (Version 7.1) (http://www.eucast.org/clinical_breakpoints/) using amoxicillin $(25 \mu \mathrm{g})$, amoxicillin/clavulanic acid $(20 / 10 \mu \mathrm{g})$, aztreonam $(30 \mu \mathrm{g})$, cefepime $(30 \mu \mathrm{g})$, cefotaxime $(30 \mu \mathrm{g})$, cefoxitin $(30 \mu \mathrm{g})$, ceftazidime $(30 \mu \mathrm{g})$, cephalexin $(30 \mu \mathrm{g})$, chloramphenicol $(30 \mu \mathrm{g})$, colistin $(50 \mu \mathrm{g})$, ertapenem $(10 \mu \mathrm{g})$, fosfomycin $(200 \mu \mathrm{g})$, gentamicin $(10 \mu \mathrm{g})$, imipenem $(10 \mu \mathrm{g})$, levofloxacin $(5 \mu \mathrm{g})$, nalidixic acid (30 UI), netilmicin $(10 \mu \mathrm{g})$, ofloxacin $(5 \mu \mathrm{g})$, piperacillin/tazobactam $(30 / 6 \mu \mathrm{g})$, piperacillin $(30 \mu \mathrm{g})$, temocillin $(30 \mu \mathrm{g})$, 
tetracycline $(30 \mu \mathrm{g})$, ticarcillin/clavulanic acid $(75 / 10 \mu \mathrm{g})$, ticarcillin $(75 \mu \mathrm{g})$, tobramycin $(10 \mu \mathrm{g})$, and trimethoprim/sulfonamide $(1.25 / 23.75 \mu \mathrm{g})$.

The ESBL genes were identified by PCR using primers, the sequences of which are listed in Table 1 [34-36]. For molecular identification of ESBL genes, DNA was extracted by the boiling method, which was employed on a single colony of each isolate in a final volume of $100 \mu \mathrm{L}$ of distilled water by incubation at $95^{\circ} \mathrm{C}$ for $10 \mathrm{~min}$ followed by a centrifugation step [37]. The thermal cycling program consisted of initialising denaturation at $95{ }^{\circ} \mathrm{C}$ for $2 \mathrm{~min}$, followed by 30 cycles of denaturation at $95^{\circ} \mathrm{C}$ for $45 \mathrm{~s}$. Hybridisation was carried out for $30 \mathrm{~s}$ (temperature was dependent on the primer (SHV: $59^{\circ} \mathrm{C}$, TEM: $63^{\circ} \mathrm{C}, \mathrm{CTX}-\mathrm{M}: 57^{\circ} \mathrm{C}$ )) along with extension at $72{ }^{\circ} \mathrm{C}$ for $30 \mathrm{~s}$, with a final elongation step at $72{ }^{\circ} \mathrm{C}$ for $5 \mathrm{~min}$. DNA from reference blaCTX-M-, blaTEM- and blaSHV-like-positive isolates was used as a positive control. PCR products were visualized after electrophoresis on $1.5 \%$ agarose gels containing ethidium bromide run at $100 \mathrm{~V}$ for $80 \mathrm{~min}$. A $100 \mathrm{bp}$ DNA ladder (Promega, USA) was used as a size marker. PCR products were purified using the ExoSAP-IT purification kit (GE Healthcare, Piscataway, NJ, USA) and sequenced by Sanger sequencing (first-generation sequencing) at Microsynth Seqlab AG (Göttingen Hannah-Vogt-Str.1, DE-37085 Göttingen). Nucleotide sequence alignment was done using the Mega 7 software at Microsynth Seqlab AG (Göttingen Hannah-Vogt-Str.1, DE-37085 Göttingen). Analysis and identification of these sequences were performed online using the BLAST programme available at the National Center for Biotechnology Information web page (http://www.ncbi.nlm.nih.gov).

Table 1. The different primers used for polymerase chain reaction (PCR) and bacterial identification.

\begin{tabular}{clccc}
\hline Primers & \multicolumn{1}{c}{ Sequences } & Basic Pair Length & Hybridization Temperature & References \\
\hline SHV-F & $5^{\prime}$-GATGAACGCTTTCCCATGATG-3' & $214 \mathrm{bp}$ & \multirow{2}{*}{$59^{\circ} \mathrm{C}$} & {$[36]$} \\
SHV-R & $5^{\prime}$-CGCTGTTATCGCTCATGGTAA-3' & & \multirow{2}{*}{$63^{\circ} \mathrm{C}$} & {$[36]$} \\
\hline TEM-F & $5^{\prime}$-AGTGCTGCCATAACCATGAGTG-3' & $550 \mathrm{bp}$ & $57^{\circ} \mathrm{C}$ & {$[36]$} \\
TEM-R & $5^{\prime}$-CTGACTCCCCGTCGTGTAGATG-3' & & & \multirow{2}{*}{$909 \mathrm{bp}$} \\
\hline $\begin{array}{l}\text { CTX UNIV-F } \\
\text { CTX UNIV-R }\end{array}$ & $5^{\prime}$-TCTTCCAGAATAAGGAATCCC-3' & $5^{\prime}$-CCGTTTCCGCTATTACAAAC-3' & & \\
\hline
\end{tabular}

\subsection{Phylogenetic Analyses}

Based on the examination of the relationship between the blaCTX-M-15 and blaSHV-11 sequences obtained by known sequences, phylogenetic trees were constructed using a set of reference sequences from GenBank. Phylogenetic analyses using ClustalW (v. 1.8.1 in BioEdit v. 7.0.9.0 software, Ibis Therapeutics, Carlsbad, CA, USA), were performed with a multiple alignment matrix of obtained partial blaCTX-M-15 and blaSHV-11 sequences and the GenBank reference sequences. For three constructions, we used the maximum likelihood (ML) method. The best-fitting ML model based on the Akaike information criterion was general time reversible (GTR) + Gamma + I (invariant sites). To finalize the construction, the tree was obtained by using PhyML $[38,39]$ with nearest-neighbour interchange (NNI) + subtree pruning regrafting (SPR) branch swapping and 1000 bootstrap replicates.

\subsection{Statistical Analyses}

Data on identified bacterial species and antibiotic susceptibility testing were collected, cleaned, and entered into Statistical Package for Social Sciences (SPSS) 20.0 (SPSS Inc., Chicago, IL, USA). These data were analyzed using descriptive statistics, frequencies and bivariate analyzes (cross tables).

\subsection{Accession Numbers}

The genomes of all genes were deposited in NCBI/GenBank under the institutional numbers $\mathrm{CH} 8$ (2) CTX-M-15 [MK559056], CH17 (2) CTX-M-15 [MK559065], CH18 (3) CTX-M-15 [MK559057], CH38

(2) CTX-M-15 [MK559063], CH41 (1) CTX-M-15 [MK559058], CH41 (2) CTX-M-15 [MK559064], CH42 (1) CTX-M-15 [MK559059], CH42 (2) CTX-M-15 [MK559060], CH43 (1) CTX-M-15 [MK559066], CH71 
(1) CTX-M-15 [MK559061], CH82 (1) CTX-M-15 [MK559062], CH38 (2) SHV-11 [MK590053], CH42 (2) SHV-11 [MK590054] and CH43 (1) SHV-11 [MK590055].

\section{Results}

\subsection{Enterobacteria Found in Bat Faecal Samples}

Over the two capture sessions, 46 Epomops franqueti and 22 Megaloglossus woermanni were caught; a total of 68 bats of the Pteropodidae family were collected. Of the 68 bacterial strains identified, 66 were Gram-negative bacteria (GNB). Among the GNB, 29 (42.65\%) were enterobacteria, which consisted of $11(37.93 \%)$ Escherichia coli, five (17.24\%) Klepsiella pneumoniae, three (10.34\%) Enterobacter aerogenes, two (5.88\%) Enterobacter cloacae, two (6.89\%) Serratia plymuthica, one Citrobacter freundii (3.45\%), one (3.45\%) Enterobacter hormaechei, one (3.45\%) Ewingella americana, one (3.45\%) Morganella morganii, one (3.45\%) Pantoea sp., and one (3.45\%) Proteus vulgaris (Table 2). The double-disk diffusion test revealed synergies that confirmed the presence of ESBLs in six $(20.69 \%)$ E. coli isolates, four $(13.79 \%)$ K. pneumoniae isolates, and one (3.45\%) E. cloacae isolate (Table 2).

Table 2. Bacterial strains isolated from fruit bats.

\begin{tabular}{ccc}
\hline Enterobacteria Strains & $\begin{array}{c}\text { Isolates } \\
\boldsymbol{n = 2 9}\end{array}$ & $\begin{array}{c}\text { ESBL Detected } \\
\boldsymbol{n} \mathbf{( \% )}\end{array}$ \\
\hline Citrobacter freundii & $1(3.45)$ & 0 \\
Enterobacter aerogenes & $3(10.34)$ & 0 \\
Enterobacter cloacae & $2(6.89)$ & $1(3.45)$ \\
Enterobacter hormaechei & $1(3.45)$ & 0 \\
Escherichia coli & $11(37.93)$ & $6(20.69)$ \\
Ewingella americana & $1(3.45)$ & 0 \\
Klebsiella pneumoniae & $5(17.24)$ & $4(13.79)$ \\
Morganella morganii & $1(3.45)$ & 0 \\
Pantoea sp. & $1(3.45)$ & 0 \\
Proteus vulgaris & $1(3.45)$ & 0 \\
Serratia plymuthica & $2(6.89)$ & 0 \\
\hline
\end{tabular}

\subsection{Antibiotic Susceptibility}

Antibiotic susceptibility tests yielded 11 (37.93\%) ESBL-producing enterobacteria. Among betalactams, resistance was observed by using amoxicillin $(100 \%)$, ticarcillin $(100 \%)$, cefotaxime $(100 \%)$, ceftazidime $(100 \%)$, cefpodoxime $(100 \%)$, aztreonam $(100 \%)$, ticarcillin/clavulanic acid $(90.90 \%)$, piperacillin $(90.90 \%)$, cephalexin $(100 \%)$, cefepime $(81.81 \%)$, amoxicillin/clavulanic acid $(54.54 \%)$, cefoxitin $(54.54 \%)$, ertapenem $(36.36 \%)$, piperacillin/tazobactam $(54.54 \%)$, and imipenem $(0.00 \%)$ (Table 3).

As for other antibiotics tested on these positive ESBL strains, resistance was observed as follows: Erythromycin $(100 \%)$, streptomycin $(100 \%)$, ciprofloxacin $(90.90 \%)$, kanamycin $(81.81 \%)$, tetracycline $(81.81 \%)$, trimethoprim/sulfamethoxazole $(72.72 \%)$, gentamycin $(63.63 \%)$, nalidixic acid $(63.63 \%)$, tobramycin $(63.63 \%)$, colistin $(54.54 \%)$, ofloxacin $(54.54 \%)$, levofloxacin $(45.45 \%)$, netilmicin $(36.36 \%)$, amikacin $(27.27 \%)$, nitrofurantoin $(18.18 \%)$, and chloramphenicol $(0 \%)$ (Table 3$)$.

Seven ESBL-producing Enterobacteriaceae from E. franqueti bats species and four ESBL-producing Enterobacteriae from $M$. woermanni bats species were identified. These bats belong to the family of Pteropodidae (Table 4). ESBL-producing enterobacteria generally showed resistance to amoxicillin, amoxicillin/clavulanic acid, ticarcillin, ticarcillin/clavulanic acid, piperacillin, piperacillin/tazobactam, cephalexin, cefotaxime, ceftazidime, cefpodoxime, aztreonam and cefepime (Table 4). Genetic analysis of ESBL resistance genes by PCR yielded only two types of genes: blaCTX-M-15, with a molecular weight of $214 \mathrm{bp}$, and blaSHV-11, with a molecular weight of $909 \mathrm{pb}$ (Table 4). 
Table 3. Prevalence of antibiotic resistance in enteric bacterial strains carrying resistance for beta-lactams.

\begin{tabular}{|c|c|c|c|c|}
\hline \multirow{2}{*}{ Antibiotic Agent } & \multicolumn{4}{|c|}{ Number and Percentage (\%) of ESBL-Producing Enterobacteria Strains by Species } \\
\hline & $\begin{array}{l}\text { E. cloacae } \\
\quad(n=1)\end{array}$ & $\begin{array}{l}\text { E. coli } \\
(n=6)\end{array}$ & $\begin{array}{c}\text { K. pneumoniae } \\
(n=4)\end{array}$ & $\begin{array}{c}\text { Total } \\
(n=11)\end{array}$ \\
\hline Amoxicillin & $1(100)$ & $6(100)$ & $4(100)$ & $11(100)$ \\
\hline Ampicillin & $1(100)$ & $6(100)$ & $4(100)$ & $11(100)$ \\
\hline Amoxicillin/clavulanic acid & $1(100)$ & $1(16.16)$ & $4(100)$ & $6(54.54)$ \\
\hline Ticarcillin & $1(100)$ & $6(100)$ & $4(100)$ & $11(100)$ \\
\hline Ticarcillin/clavulanic acid & $1(100)$ & $5(83.33)$ & $4(100)$ & $10(90.90)$ \\
\hline Piperacillin & $1(100)$ & $5(83.33)$ & $4(100)$ & $10(90.90)$ \\
\hline Piperacillin/tazobactam & $1(100)$ & 0 & $2(50)$ & $3(27.27)$ \\
\hline Cephalexin & $1(100)$ & $6(100)$ & $4(100)$ & $11(100)$ \\
\hline Cefoxitin & $1(100)$ & $2(33.33)$ & $3(75)$ & $6(54.54)$ \\
\hline Cefotaxime & $1(100)$ & $6(100)$ & $4(100)$ & $11(100)$ \\
\hline Cefpodoxime & $1(100)$ & $6(100)$ & $4(100)$ & $11(100)$ \\
\hline Ceftazidime & $1(100)$ & $6(100)$ & $4(100)$ & $11(100)$ \\
\hline Cefepime & $1(100)$ & $4(66.67)$ & $4(100)$ & $9(81.81)$ \\
\hline Aztreonam & $1(100)$ & $6(100)$ & $4(100)$ & $11(100)$ \\
\hline Imipenem & 0 & 0 & 0 & 0 \\
\hline Ertapenem & $1(100)$ & $2(33.33)$ & $1(25)$ & $4(36.36)$ \\
\hline Amikacin & $1(100)$ & $2(33.33)$ & 0 & $3(27.27)$ \\
\hline Gentamycin & $1(100)$ & $2(33.33)$ & $4(80)$ & $7(63.63)$ \\
\hline Kanamycin & $1(100)$ & $4(66.67)$ & $4(100)$ & $9(81.81)$ \\
\hline Netilmicin & 0 & $2(33.33)$ & $2(50)$ & $4(36.36)$ \\
\hline Streptomycin & $1(100)$ & $6(100)$ & $4(100)$ & $11(100)$ \\
\hline Tobramycin & $1(100)$ & $3(50)$ & $3(60)$ & $7(63.63)$ \\
\hline Erythromycin & $1(100)$ & $6(100)$ & $4(100)$ & $11(100)$ \\
\hline Fosfomycin & $1(100)$ & $1(16.16)$ & $2(40)$ & $4(36.36)$ \\
\hline Tetracycline & 0 & $5(83.33)$ & $4(100)$ & $9(81.81)$ \\
\hline Colistin & $1(100)$ & $1(9.09)$ & $4(80)$ & $6(54.54)$ \\
\hline Trimethoprim/sulfamethoxazole & 0 & $4(66.67)$ & $4(100)$ & $8(72.72)$ \\
\hline Chloramphenicol & 0 & 0 & 0 & 0 \\
\hline Nalidixic acid & $1(100)$ & $2(33.33)$ & $4(100)$ & $7(63.63)$ \\
\hline Ciprofloxacin & $1(100)$ & $5(83.33)$ & $4(100)$ & $10(90.90)$ \\
\hline Ofloxacin & 0 & $3(50)$ & $3(60)$ & $6(54.54)$ \\
\hline Levofloxacin & 0 & $2(33.33)$ & $3(60)$ & $5(45.45)$ \\
\hline Nitrofurantoin & 0 & 0 & $2(50)$ & $2(18.18)$ \\
\hline
\end{tabular}

In our findings, E. coli was the main enterobacterial species that was resistant to ESBLs, followed by K. pneumoniae and E. cloacae. The analysis of the nucleotide sequences resulting from the sequencing of the ESBL resistance genes showed that all blaCTX-Ms were blaCTX-M-15 and all blaSHVs were blaSHV-11, according to the following distribution: 54.54\% ESBL (CTX-M-15)-producing E. coli, 9.09\% ESBL (CTX-M-15)-producing K. pneumoniae, 27.27\% ESBL (CTX-M-15, SHV-11)-producing K. pneumoniae and $9.09 \%$ ESBL (CTX-M-15)-producing E. cloacae (Table 4).

Phylogenetic analyses revealed that all the sequences obtained in bats that carry blaCTX-M-15 (see Table 4) clustered with human bacterial strains carrying blaCTX-M-15 from Turkey (Figure 1). Four sequences carrying blaSHV-11 from K. pneumoniae isolates provided from bats (CH43 (1)_SHV-11, CH43 (2)_SHV-11, CH42 (2)_SHV-11 and CH38 (2)_SHV-11) clustered with human bacterial strains from Tunisia (Figure 2). 
Table 4. Antibiotic resistance profiles of Extended spectrum Beta-lactamase (ESBL)-producing Enterobacteriae from bats belonging to the family of Pteropodidae.

\begin{tabular}{|c|c|c|c|c|}
\hline Colony & Species of Bat & Bacterial Strain & Profiles of ESBL-Producing Enterobacteriae & ESBL Gene \\
\hline CH $82(1)$ & Epomops franqueti & E. coli & AX-TIC-PRL-CL-CTX-CAZ-CPD-ATM-AMP-TE-STR-SXT-ERY & blaCTX-M-15 \\
\hline CH 71 (1) & E. franqueti & E. coli & AX-TIC-TIM-PRL-CL-CTX-CAZ-CPD-ATM-AMP-ERT-CIP-OFX-STR-ERY-SXT-TE & blaCTX-M-15 \\
\hline CH 41 (1) & E. franqueti & E. coli & AX-TIC-TIM-PRL-CL-FOX-CTX-CAZ-CPD-FEP-ATM-AMP-CIP-KAN-CT-E-STR-TE & blaCTX-M-15 \\
\hline CH 42 (1) & Megaloglossus woermanni & E. coli & AX-TIC-TIM-PRL-CL-CTX-CAZ-CPD-FEP-ATM-AMP-CIP-OFX-LEV-AK-CN-KAN-STR-ERY-TOB-SXT-TE & blaCTX-M-15 \\
\hline CH 18 (3) & M. woermanni & E. coli & AX-TIC-TIM-CL-FOX-CTX-CAZ-CPD-FEP-ATM-AMP-ERT-NA-CIP-AK-CN-KAN-NET-STR-E-TOB-CT-FOS & blaCTX-M-15 \\
\hline $\mathrm{CH} 41$ (2) & M. woermanni & E. coli & AX-AMC-TIC-TIM-PRL-CL-CTX-CAZ-CPD-FEP-ATM-AMP-NA-CIP-OFX-LEV-KAN-NET-STR-ERY-TOB-SXT-TE & blaCTX-M-15 \\
\hline $\mathrm{CH} 8(2)$ & E. franqueti & E. cloacae & AX-AMC-TIC-TIM-PRL-TPZ-CL-FOX-CTX-CAZ-CPD-FEP-ATM-ERT-NA-CIP-AK-CN-KAN-STR-TOB-CT-FOS & blaCTX-M-15 \\
\hline $\mathrm{CH} 17(2)$ & E. franqueti & K. pneumoniae & AX-AMC-TIC-TIM-PRL-CTX-CAZ-CPD-FEP-ATM-CIP-OFX-KAN-CT & blaCTX-M-15 \\
\hline $\mathrm{CH} 43(1)$ & E. franqueti & K. pneumoniae & AX-AMC-TIC-TIM-PRL-TPZ-CL-FOX-CTX-CAZ-CPD-FEP-ATM-CIP-CN-KAN-STR-CT-FTN-SXT-TE- & $\begin{array}{c}\text { blaCTX-M-15, } \\
\text { blaSHV-11 }\end{array}$ \\
\hline $\mathrm{CH} 42(2)$ & M. woermanni & K. pneumoniae & AX-AMC-TIC-TIM-PRL-CL-FOX-CTX-CAZ-CPD-FEP-ATM-NA-CIP-CN-KAN-NET-S-TOB-CT-TE-SXT & $\begin{array}{c}\text { blaCTX-M-15, } \\
\text { blaSHV-11 }\end{array}$ \\
\hline $\mathrm{CH} 38(2)$ & E. franqueti & K. pneumoniae & AX-AMC-TIC-TIM-PRL-TPZ-CL-FOX-CTX-CAZ-CPD-FEP-ATM-ERT-CIP-OFX-LEV-TOB-CN-KAN-NET-STR-FOS-TE-SXT & $\begin{array}{c}\text { blaCTX-M-15, } \\
\text { blaSHV-11 }\end{array}$ \\
\hline
\end{tabular}

$\mathrm{AX}=$ Amoxicillin, $\mathrm{AMC}=$ Amoxicillin/Clavulanic Acid, TIC $=$ Ticarcillin, $\mathrm{TIM}=$ Ticarcillin/Clavulanic Acid, $\mathrm{PRL}=$ Piperacillin, TZP $=$ Piperacillin/Tazobactam, $\mathrm{CL}=\mathrm{Cephalexin}, \mathrm{FOX}=$ Cefoxitin, $\mathrm{CTX}=$ Cefotaxime, $\mathrm{CAZ}=$ Ceftazidime, $\mathrm{CPD}=$ Cefpodoxime, $\mathrm{FEP}=$ Cefepime, $\mathrm{ATM}=$ Aztreonam, ERT = Ertapenem, IMP $=\mathrm{Imipenem}, \mathrm{TOB}=\mathrm{Tobramycin}, \mathrm{KAN}=\mathrm{Kanamycin}$, $\mathrm{AK}=$ Amikacin, NET = Netilmicin, $\mathrm{CN}=$ Gentamycin, NA = Nalidixic Acid, CIP = Ciprofloxacin, OFX = Ofloxacin, LEV = Levofloxacin, FOS = Fosfomycin, TE = Tetracycline, $\mathrm{SXT}=$ Sulfamethoxazole + Trimethoprim, C = Chloramphenicol, CT = Colistin; CTX-M = Cefotaximase-Munich; SHV = Sulfhydryl Variable, STR = Streptomycin, ERY = Erythromycin, FTN = Nitrofurantoin, $\mathrm{CH}=$ Chauve-souris (bats). 


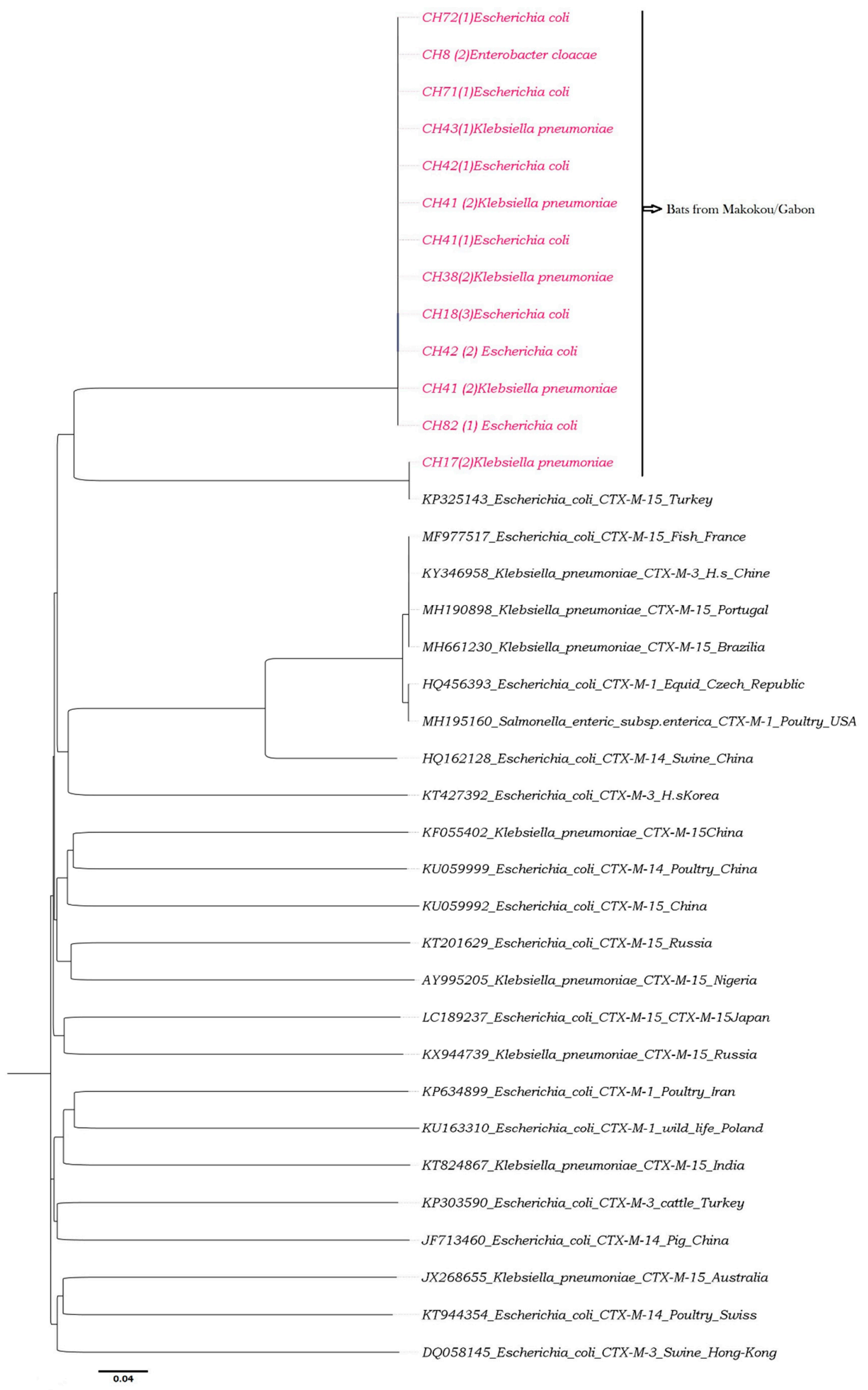

Figure 1. Phylogeny of CTX-M-15 from bats. 


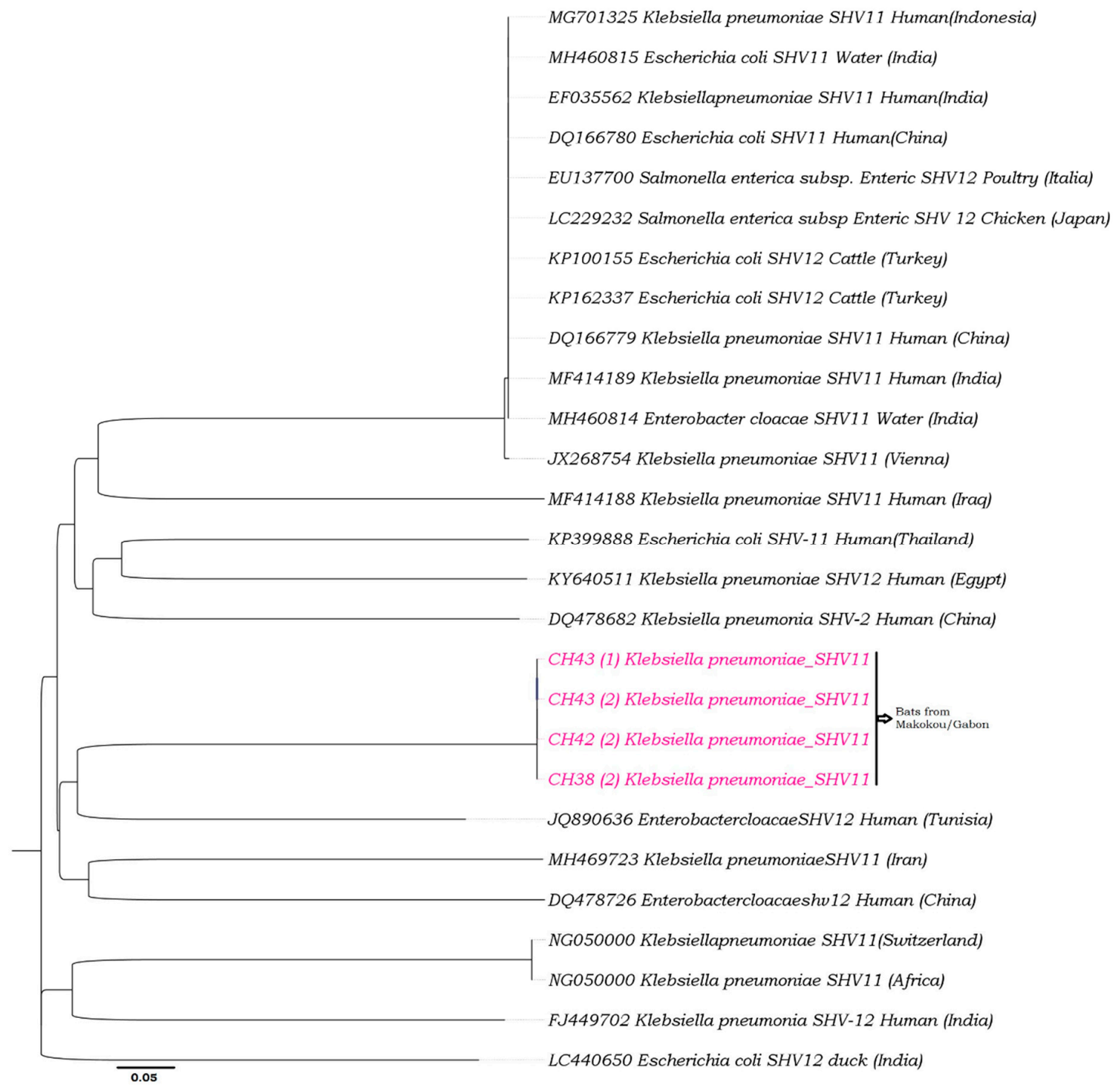

Figure 2. Phylogeny of SHV-11 from bats.

\section{Discussion}

Some studies have demonstrated that bats can carry antibiotic resistance $[6,10,13,15,40,41]$. Similar results were found in this study, but the E. coli strains were isolated from three E. franqueti and three M. woermanni, two Pteropodidae bats with different ecologies. E. coli is considered to be common in the physiological intestinal flora of megachiropteran bats [42,43].

The beta-lactam resistance phenotypes obtained in our study are also comparable to those obtained in a study on bats in Algeria [11], which showed resistance to amoxicillin, amoxicillin/clavulanic acid, aztreonam, cefotaxime, cefoxitin and ceftazidime. However, no ESBL resistance was found in bats in Algeria. Our study also revealed higher resistance to tetracycline (81.81\%), ciprofloxacin $(90.90 \%)$, and ofloxacin $(54.54 \%)$ compared with that of a study carried out in Nigeria [15]. Moreover, in our data, CTX-M-15 was found either as a single resistance determinant in E. coli (54.54\%) and E. cloacae and K. pneumoniae $(9.09 \%)$ or was associated with SHV-11 in K. pneumoniae $(27.27 \%)$. The prevalence of ESBL-producing enterobacteria (37.93\%) was higher than that obtained in E. coli sampled in bats and other wild animals in Nigeria $[13,15]$ and the Republic of Congo [44], in which no phenotype of ESBL resistance was found. The CTX-M-15-producing K. pneumoniae was found in a gorilla in its natural habitat in the Dzanga Ndoki National Park [27]. CTX-M-15 is the most highly detected genotype in human clinical settings [45,46] and in Tadarida teniotis (bats) in Portugal [12]. Enterobacteria producing 
ESBL have already been found on all continents, and the most frequently encountered is E. coli, followed by K. pneumoniae [47]. However, blaCTX-M beta-lactam resistance genes are the most common in the human and veterinary strains [48-50]. blaCTX-M-15 is the most prevalent ESBL gene in human samples worldwide [25] and is probably the most widely distributed ESBL gene in human strains around the world [23]. In addition, blaCTX-M-15 and blaSHV-11 genes are recognized as plasmid-mediated resistance genes $[27,51]$. All of these studies show that carriage of antibiotic resistance among wildlife species may vary locally but is linked to the antibiotics used by humans $[10,52,53]$.

In Gabon, the blaCTX-M-15 genes had already been identified in ESBL-producing Enterobacteriaceae from patients in the Albert Schweitzer Hospital in Lambaréné and in poultry [31,32]. The presence of antibiotic resistance linked to blaCTX-M-15 and blaSHV-11 genes is probably linked to antibiotics used by humans, since our phylogenetic analyses show that all the sequences obtained in bats that carry CTX-M-15 or SHV-11 clustered with one human bacterial strain from Turkey and Tunisia, respectively. This suggests that the prevalence of antibiotic resistance in wild animals depends on the antibiotics consumed by human populations at each site and the density of the human population in contact with fauna [44].

In our samples, the highest prevalence of resistance was obtained in resistance to aminoglycosides (kanamycin, tobramycin and streptomycin), fluoroquinolones (ciprofloxacin and nalidixic acid) and tetracycline, which are the most common antibiotics consumed by the Gabonese people [21,54]. The congruence between the resistance prevalence and the frequency of antibiotics consumed by local people was also observed in Portugal [12] but not in Nigeria [15]. The low percentage of carbapenem resistance in our study suggests that these antibiotics are still very active against multiresistant strains [55]. Antibiotic resistance among E. coli isolated from wildlife may be acquired from the food [56-59] they consume, the environment [60] and water [61]; resistance may also reflect the use of antimicrobials in humans and livestock [15,52]. Further, foodborne transmission of multiresistant E. coli has already been described as an important source of infection in mammals [15]. Foodborne diseases such as pathogenic E. coli infections can result from food contamination [59]. We can therefore explain the transmission of antibiotic resistance observed in our study in three main ways. First, fruit bats may be contaminated by other mammals that already carry this type of resistance by eating the same fruits when sharing the same ecosystem [62,63]. Second, fruit bats may also be contaminated by drinking wastewater [61,64]. Most bats use open water sources for drinking water [65-68], like pools in streams, lakes, ponds, slow-flowing streams, and rivers [69,70]. These sources of water are frequently polluted, in particular near cities [61]. Several studies provide much evidence that waste water effluent and surface water are important sources of the dissemination of ESBLs in the natural environment and in particular in Africa [71-73]. Third, we captured some bats by hanging nets on mango branches $2 \mathrm{~m}$ behind human dwellings and $1 \mathrm{~km}$ away from the hospital. Besides these mango trees, there were other fruit trees, such as Aridan trees (Tetrapleura tetraptera, the fruit of which is widely consumed in Gabon) and lemon. Hence, it is possible that some fruits partly eaten by humans and contaminated have been ingested by bats. Fruit bats are potential vectors and reservoirs of pathogenic bacteria such as E. coli, which carry acquired resistance [2,41,59]. The risk to human health stems from the transmission of these pathogens from fruit bats to humans because fruits contaminated (half eaten or masticated fruits) by bats might be eaten by humans $[2,59,74,75]$. Bats can also contaminate human drinking water [61]. In this case, it would be a serious public health problem.

The phylogeny of CTX-M-15 was constructed using v. 1.8.1 in BioEdit v. 7.0.9.0 software. These analyses were performed with a multiple alignment matrix of obtained partial CTX-M-15 sequences and the GenBank reference sequences of human, poultry and swine from Africa (Nigeria), Asia (Japan, China and Hong Kong), Europe (France, Turkey, Poland, Russia, Switzerland, and Czech Republic), the Middle East (Iran), and South America (Brazil). Enterobacteriaceae carrying CTX-M-15 isolated from fruit bats of Makokou in Gabon (in pink color).

The phylogeny of SHV-11 was constructed using v. 1.8.1 in BioEdit v. 7.0.9.0 software. These analyses were performed with a multiple alignment matrix of obtained partial SHV-11 sequences 
and the GenBank reference sequences of human, water and cattle from Europe (Italy, Russia and Switzerland), Asia (China, Indonesia, India and Thailand), the Middle East (Iran), and Africa (Tunisia and Egypt). All sequences of SHV-11 were from K. pneumoniae from bats. Enterobacteriaceae carrying SHV-11 isolated from fruit bats of Makokou in Gabon (in pink color).

\section{Conclusions}

This study showed for the first time the presence of multiresistant ESBL-producing enterobacteria in Makokou fruit bats in Gabon (Central Africa). The source of the contamination has not been clearly determined, but the presence of this type of resistance in bats suggests that these wild mammals could spread ESBL-producing Enterobacteriacea over long distances or across the urban landscape.

Our results reinforce the need to monitor antimicrobial resistance in wild animals, in protected or unprotected areas, in order to assess environmental responses to anthropogenic pressures.

Author Contributions: Formal analysis, P.P.M.N., J.C.O.M., A.M.M., M.Y., M.L., Y.D. and Z.F.Z.; Funding acquisition, R.O. and F.B.; Investigation, P.P.M.N. and A.M.M.; Methodology, P.P.M.N., R.O., G.R.N.A., A.M.M. and M.Y.; Project administration, F.B., R.O.; Software, J.C.O.M.; Supervision, R.O., S.G. and F.B.; Writing-original draft, P.P.M.N.; Writing-review and editing, P.P.M.N., R.O., F.B. and S.G. All authors have read and agreed to the published version of the manuscript.

Funding: The capture of bats and collection of their feces were performed thanks to funding by the EBOFAQ project. The bacterial analysis and antibiotic susceptibility were done thanks to the grant (grant numbers G950/BACGL 2015/AO/PFD) from the Agence Universitaire de la Francophonie (AUF).

Acknowledgments: The capture of bats was performed as part of the EBOFAQ project by Eric LEROY (former General Manager of CIRMF). The analysis of bat fecal samples was done thanks to a grant from the Agence Universitaire de la Francophonie (AUF). We thank the CIRMF and AUF for this opportunity. Special thanks to Eric LEROY and Gaël Darren (MAGANGA) for integrating us in their mission of bat capture, Olivier THALLER and Arnaud MARTIN of the University of Montpellier for their helpful comments and Kazunari USHIDA and Sayaka TUCHIDA for training us on bacteriological studies in forests and all of their useful advice and remarks.

Conflicts of Interest: The authors declare no conflict of interest. The funders had no role in the design of the study; in the collection, analyses, or interpretation of data; in the writing of the manuscript, or in the decision to publish the results.

\section{References}

1. Cláudio, V.C.; Gonzalez, I.; Barbosa, G.; Rocha, V.; Moratelli, R.; Rassy, F. Bacteria richness and antibiotic-resistance in bats from a protected area in the Atlantic Forest of Southeastern Brazil. PLoS ONE 2018, 13, e0203411. [CrossRef] [PubMed]

2. Allocati, N.; Petrucci, A.; Di Giovanni, P.; Masulli, M.; Di Ilio, C.; De Laurenzi, V. Bat-man disease transmission: Zoonotic pathogens from wildlife reservoirs to human populations. Cell Death Discov. 2016, 2, 16048. [CrossRef] [PubMed]

3. Dietrich, M.; Kearney, T.; Seamark, E.C.; Markotter, W. The excreted microbiota of bats: Evidence of niche specialisation based on multiple body habitats. FEMS Microbiol. Lett. 2017, 364, fnw284. [CrossRef] [PubMed]

4. Mühldorfer, K. Bats and bacterial pathogens: A review. Zoonoses Public Health 2013, 60, 93-103. [CrossRef]

5. Graves, S.; Kennelly-Merrit, S.; Tidemann, C.; Rawlinson, P.; Harvey, K.; Thornton, I. Antibiotic-resistance patterns of enteric bacteria of wild mammals on the Krakatau Islands and West Java, Indonesia. Philos. Trans. R. Soc. Lond. B Biol. Sci. 1988, 322, 339-353. [CrossRef]

6. McDougall, F.; Boardman, W.; Gillings, M.; Power, M. Bats as reservoirs of antibiotic resistance determinants: A survey of class 1 integrons in Grey-headed Flying Foxes (Pteropus poliocephalus). Infect. Genet. Evol. 2019, 70, 107-113. [CrossRef]

7. Streicker, D.G.; Turmelle, A.S.; Vonhof, M.J.; Kuzmin, I.V.; McCracken, G.F.; Rupprecht, C.E. Host phylogeny constrains cross-species emergence and establishment of rabies virus in bats. Science 2010, 329, 676-679. [CrossRef]

8. Dolejska, M.; Papagiannitsis, C.C. Papagiannitsis, Plasmid-mediated resistance is going wild. Plasmid 2018, 99, 99-111. [CrossRef] 
9. Adesiyun, A.; Downes, M. Prevalence of antimicrobial resistance and enteropathogenic serogroups in Escherichia coli isolates. Vet. Arhiv 1999, 69, 335-347.

10. Benavides, J.; Shiva, C.; Virhuez, M.; Tello, C.; Appelgren, A.; Vendrell, J.; Solassol, J.; Godreuil, S.; Streicker, D. Extended-spectrum beta-lactamase-producing Escherichia coli in common vampire bats Desmodus rotundus and livestock in Peru. Zoonoses Public Health 2018, 65, 454-458. [CrossRef]

11. Djedjiga, A.C.C. Etude de la Flore Bactérienne Résistante aux Antibiotiques chez les Chauves-Souris. Mémoires de Master. 2017. Available online: http://www.univ-bejaia.dz/dspace/handle/123456789/204 (accessed on 28 December 2018).

12. Garcês, A.; Correia, S.; Amorim, F.; Pereira, J.; Igrejas, G.; Poeta, P. First report on extended-spectrum beta-lactamase (ESBL) producing Escherichia coli from European free-tailed bats (Tadarida teniotis) in Portugal: A One-Health approach of a hidden contamination problem. J. Hazard. Mater. 2017, 370, $219-224$. [CrossRef] [PubMed]

13. Iroha, I.; Afiukwa, F.; Oji, A.; Ejikeugwu, P.; Nwakeze, E. Occurrence of extended spectrum beta lactamase producing Escherichia coli from human clinical and wild birds (pigeons, bats, parrots and ducks) samples from Ebonyi state, Nigeria. World J. Pharm. Sci. 2015, 4, 20-29.

14. Obi, T.; Chibana, M.; Taira, C.; Nakayama, A.; Miyazaki, K.; Takase, K.; Nakamura, I.; Miyamoto, A.; Kawamoto, Y. Antimicrobial susceptibility in Enterobacteriaceae recovered from Okinawa least horseshoe bat Rhinolophus pumilus. Wildl. Biol. 2014, 20, 64-66. [CrossRef]

15. Oluduro, A.O. Antibiotic-resistant commensal Escherichia coli in faecal droplets from bats and poultry in Nigeria. Vet. Ital. 2012, 48, 297-308.

16. Hassell, J.M.; Ward, M.J.; Muloi, D.; Bettridge, J.M.; Robinson, T.P.; Kariuki, S.; Ogendo, A.; Kiiru, J.; Imboma, T.; Kang'ethe, E.K. Clinically relevant antimicrobial resistance at the wildlife-livestock-human interface in Nairobi: An epidemiological study. Lancet Planet. Health 2019, 3, e259-e269. [CrossRef]

17. Ambler, R.; Coulson, A.; Frere, J.-M.; Ghuysen, J.-M.; Joris, B.; Forsman, M.; Levesque, R.; Tiraby, G.; Waley, S. A standard numbering scheme for the class A beta-lactamases. Biochem. J. 1991, 276 Pt 1, 269. [CrossRef]

18. Paterson, D.L.; Bonomo, R.A. Extended-spectrum $\beta$-lactamases: A clinical update. Clin. Microbiol. Rev. 2005, 18, 657-686. [CrossRef]

19. Sosa, A.D.J.; Amábile-Cuevas, C.F.; Byarugaba, D.K.; Hsueh, P.-R.; Kariuki, S.; Okeke, I.N. Antimicrobial Resistance in Developing Countries; Springer: New York, NY, USA, 2010.

20. Bradford, P.A. Extended-spectrum $\beta$-lactamases in the 21st century: Characterization, epidemiology, and detection of this important resistance threat. Clin. Microbiol. Rev. 2001, 14, 933-951. [CrossRef]

21. Benavides, J.A.; Godreuil, S.; Bodenham, R.; Ratiarison, S.; Devos, C.; Petretto, M.-O.; Raymond, M.; Escobar-Páramo, P. No evidence for transmission of antibiotic-resistant Escherichia coli strains from humans to wild western lowland gorillas in Lope National Park, Gabon. Appl. Environ. Microbiol. 2012, 78, 4281-4287. [CrossRef]

22. Blanco, G.; Lemus, J.A.; Grande, J.; Gangoso, L.; Grande, J.M.; Donázar, J.A.; Arroyo, B.; Frías, O.; Hiraldo, F. Retracted Geographical variation in cloacal microflora and bacterial antibiotic resistance in a threatened avian scavenger in relation to diet and livestock farming practices. Environ. Microbiol. 2007, 9, 1738-1749. [CrossRef]

23. Cantón, R.; González-Alba, J.M.; Galán, J.C. CTX-M enzymes: Origin and diffusion. Front. Microbiol. 2012, 3, 110. [CrossRef] [PubMed]

24. Carattoli, A. Plasmids and the spread of resistance. Int. J. Med. Microbiol. 2013, 303, 298-304. [CrossRef] [PubMed]

25. Ewers, C.; Bethe, A.; Semmler, T.; Guenther, S.; Wieler, L. Extended-spectrum $\beta$-lactamase-producing and AmpC-producing Escherichia coli from livestock and companion animals, and their putative impact on public health: A global perspective. Clin. Microbiol. Infect. 2012, 18, 646-655. [CrossRef] [PubMed]

26. Hansen, K.H.; Damborg, P.; Andreasen, M.; Nielsen, S.S.; Guardabassi, L. Carriage and fecal counts of cefotaxime M-producing Escherichia coli in pigs: A longitudinal study. Appl. Environ. Microbiol. 2013, 79, 794-798. [CrossRef] [PubMed]

27. Janatova, M.; Albrechtova, K.; Petrzelkova, K.J.; Dolejska, M.; Papousek, I.; Masarikova, M.; Cizek, A.; Todd, A.; Shutt, K.; Kalousova, B. Antimicrobial-resistant Enterobacteriaceae from humans and wildlife in Dzanga-Sangha Protected Area, Central African Republic. Vet. Microbiol. 2014, 171, 422-431. [CrossRef] [PubMed] 
28. Liakopoulos, A.; Mevius, D.J.; Olsen, B.; Bonnedahl, J. The colistin resistance mcr-1 gene is going wild. J. Antimicrob. Chemother. 2016, 71, 2335-2336. [CrossRef]

29. Mbehang Nguema, P.P.; Okubo, T.; Tsuchida, S.; Fujita, S.; Yamagiwa, J.; Tamura, Y.; Ushida, K. Isolation of multiple drug-resistant enteric bacteria from feces of wild Western Lowland Gorilla (Gorilla gorilla gorilla) in Gabon. J. Vet. Med. Sci. 2015, 77, 619. [CrossRef]

30. Mbehang Nguema, P.P.; Tsuchida, S.; Ushida, K. Bacteria culturing and isolation under field conditions of Moukalaba-Doudou National Park, Gabon, and preliminary survey on bacteria carrying antibiotic resistance genes. Tropics 2015, 23, 165-174. [CrossRef]

31. Schaumburg, F.; Alabi, A.; Kokou, C.; Grobusch, M.P.; Köck, R.; Kaba, H.; Becker, K.; Adegnika, A.A.; Kremsner, P.G.; Peters, G. High burden of extended-spectrum $\beta$-lactamase-producing Enterobacteriaceae in Gabon. J. Antimicrob. Chemother. 2013, 68, 2140-2143. [CrossRef]

32. Schaumburg, F.; Alabi, A.S.; Frielinghaus, L.; Grobusch, M.P.; Köck, R.; Becker, K.; Issifou, S.; Kremsner, P.G.; Peters, G.; Mellmann, A. The risk to import ESBL-producing Enterobacteriaceae and Staphylococcus aureus through chicken meat trade in Gabon. BMC Microbiol. 2014, 14, 286. [CrossRef]

33. Bauer, A.; Kirby, W.; Sherris, J.C.; Turck, M. Antibiotic susceptibility testing by a standardized single disk method. Am. J. Clin. Pathol. 1966, 45, 493-497. [CrossRef] [PubMed]

34. Chaverri, G. Aerobic bacterial flora from the digestive tract of the common vampire bat, Desmodus rotundus (Chiroptera: Phyllostomidae). Rev. Biol. Trop. 2006, 54, 717-724. [CrossRef] [PubMed]

35. Kaur, M.; Aggarwal, A. Aggarwal, Occurrence of the CTX-M, SHV and the TEM genes among the extended spectrum $\beta$-lactamase producing isolates of Enterobacteriaceae in a tertiary care hospital of North India. J. Clin. Diagn. Res. 2013, 7, 642-645. [PubMed]

36. Thabit, A.G.; El-Khamissy, T.R.; Ibrahim, M.A.; Attia, A.E. Detection of extended-spectrum $\beta$-lactamase enzymes (ESBLs) produced by Escherichia coli urinary pathogens at Assiut University Hospital. Bull. Pharm. Sci. Assiut Univ. 2011, 34, 93-103.

37. Peng, X.; Yu, K.-Q.; Deng, G.-H.; Jiang, Y.-X.; Wang, Y.; Zhang, G.-X.; Zhou, H.-W. Comparison of direct boiling method with commercial kits for extracting fecal microbiome DNA by Illumina sequencing of $16 \mathrm{~S}$ rRNA tags. J. Microbiol. Methods 2013, 95, 455-462. [CrossRef]

38. Dereeper, A.; Guignon, V.; Blanc, G.; Audic, S.; Buffet, S.; Chevenet, F.; Dufayard, J.F.; Guindon, S.; Lefort, V.; Lescot, M.; et al. Phylogeny.fr: Robust phylogenetic analysis for the non-specialist. Nucleic Acids Res. 2008, 36, W465-W469. [CrossRef]

39. Guindon, S.; Dufayard, J.-F.; Lefort, V.; Anisimova, M.; Hordijk, W.; Gascuel, O. New algorithms and methods to estimate maximum-likelihood phylogenies: Assessing the performance of PhyML 3.0. Syst. Biol. 2010, 59, 307-321. [CrossRef]

40. Adesiyun, A.A.; Stewart-Johnson, A.; Thompson, N.N. Isolation of enteric pathogens from bats in Trinidad. J. Wildl. Dis. 2009, 45, 952-961. [CrossRef]

41. Islam, A.; Mikolon, A.; Mikoleit, M.; Ahmed, D.; Khan, S.U.; Sharker, M.Y.; Hossain, M.J.; Islam, A.; Epstein, J.H.; Zeidner, N. Isolation of Salmonella virchow from a fruit bat (Pteropus giganteus). EcoHealth 2013, 10, 348-351. [CrossRef]

42. Klite, P. Intestinal bacterial flora and transit time of three neotropical bat species. J. Bacteriol. 1965, 90, 375-379. [CrossRef]

43. Moreno, G.; Lopes, C.; Seabra, E.; Pavan, C.; Correa, A. Bacteriological study of the intestinal flora of bats (Desmodus rotundus) (author's transl). Arq. Inst. Biol. 1975, 42, 229-232.

44. Nowak, K.; Fahr, J.; Weber, N.; Lübke-Becker, A.; Semmler, T.; Weiss, S.; Mombouli, J.-V.; Wieler, L.H.; Guenther, S.; Leendertz, F.H. Highly diverse and antimicrobial susceptible Escherichia coli display a naïve bacterial population in fruit bats from the Republic of Congo. PLoS ONE 2017, 12, e0178146. [CrossRef] [PubMed]

45. Sallem, R.B.; Gharsa, H.; Slama, K.B.; Rojo-Bezares, B.; Estepa, V.; Porres-Osante, N.; Jouini, A.; Klibi, N.; Sáenz, Y.; Boudabous, A. First detection of CTX-M-1, CMY-2, and QnrB19 resistance mechanisms in fecal Escherichia coli isolates from healthy pets in Tunisia. Vector Borne Zoonotic Dis. 2013, 13, 98-102. [CrossRef] [PubMed]

46. Slama, K.B.; Sallem, R.B.; Jouini, A.; Rachid, S.; Moussa, L.; Sáenz, Y.; Estepa, V.; Somalo, S.; Boudabous, A.; Torres, C. Diversity of genetic lineages among CTX-M-15 and CTX-M-14 producing Escherichia coli strains in a Tunisian hospital. Curr. Microbiol. 2011, 62, 1794-1801. [CrossRef] 
47. Gakuya, F.; Kyule, M.; Gathura, P.; Kariuki, S. Antimicrobial resistance of bacterial organisms isolated from rats. East Afr. Med. J. 2001, 78, 646-649. [CrossRef]

48. Wang, J.; Ma, Z.-B.; Zeng, Z.-L.; Yang, X.-W.; Huang, Y.; Liu, J.-H. The role of wildlife (wild birds) in the global transmission of antimicrobial resistance genes. Zool. Res. 2017, 38, 55-80. [CrossRef]

49. Hordijk, J.; Schoormans, A.; Kwakernaak, M.; Duim, B.; Broens, E.; Dierikx, C.; Mevius, D.; Wagenaar, J.A. High prevalence of fecal carriage of extended spectrum $\beta$-lactamase/AmpC-producing Enterobacteriaceae in cats and dogs. Front. Microbiol. 2013, 4, 242. [CrossRef]

50. Wellington, E.M.; Boxall, A.B.; Cross, P.; Feil, E.J.; Gaze, W.H.; Hawkey, P.M.; Johnson-Rollings, A.S.; Jones, D.L.; Lee, N.M.; Otten, W. The role of the natural environment in the emergence of antibiotic resistance in gram-negative bacteria. Lancet Infect. Dis. 2013, 13, 155-165. [CrossRef]

51. Liakopoulos, A.; Mevius, D.; Ceccarelli, D. A review of SHV extended-spectrum $\beta$-lactamases: Neglected yet ubiquitous. Front. Microbiol. 2016, 7, 1374. [CrossRef]

52. Rolland, R.; Hausfater, G.; Marshall, B.; Levy, S. Antibiotic-resistant bacteria in wild primates: Increased prevalence in baboons feeding on human refuse. Appl. Environ. Microbiol. 1985, 49, 791-794. [CrossRef]

53. Sherley, M.; Gordon, D.M.; Collignon, P.J. Variations in antibiotic resistance profile in Enterobacteriaceae isolated from wild Australian mammals. Environ. Microbiol. 2000, 2, 620-631. [CrossRef] [PubMed]

54. Vlieghe, E.; Phoba, M.; Tamfun, J.M.; Jacobs, J. Antibiotic resistance among bacterial pathogens in Central Africa: A review of the published literature between 1955 and 2008. Int. J. Antimicrob. Agents 2009, 34, 295-303. [CrossRef] [PubMed]

55. Giacopello, C.; Foti, M.; Mascetti, A.; Grosso, F.; Ricciardi, D.; Fisichella, V.; Piccolo, F.L. Antimicrobial resistance patterns of Enterobacteriaceaein European wild bird species admitted in a wildlife rescue centre. Vet. Ital. 2016, 52, 139-144. [PubMed]

56. Aarestrup, F.M.; Wegener, H.C. The effects of antibiotic usage in food animals on the development of antimicrobial resistance of importance for humans in Campylobacter and Escherichia coli. Microbes Infect. 1999, 1, 639-644. [CrossRef]

57. Dhama, K.; Rajagunalan, S.; Chakraborty, S.; Verma, A.; Kumar, A.; Tiwari, R.; Kapoor, S. Food-borne pathogens of animal origin-diagnosis, prevention, control and their zoonotic significance: A review. Pak. J. Biol. Sci. 2013, 16, 1076. [CrossRef]

58. Heredia, N.; García, S. Animals as sources of food-borne pathogens: A review. Anim. Nutr. 2018, 4, $250-255$. [CrossRef]

59. Nowak, K. African fruit bats as potential reservoir for zoonotic pathogens-the example of Escherichia coli. Public Health 2018. [CrossRef]

60. Biyela, P.; Lin, J.; Bezuidenhout, C. The role of aquatic ecosystems as reservoirs of antibiotic resistant bacteria and antibiotic resistance genes. Water Sci. Technol. 2004, 50, 45-50. [CrossRef]

61. Korine, C.; Adams, R.; Russo, D.; Fisher-Phelps, M.; Jacobs, D. Bats and water: Anthropogenic alterations threaten global bat populations. In Bats in the Anthropocene: Conservation of Bats in a Changing World; Springer: Cham, Switzerland, 2016; pp. 215-241.

62. Guenther, S.; Aschenbrenner, K.; Stamm, I.; Bethe, A.; Semmler, T.; Stubbe, A.; Stubbe, M.; Batsajkhan, N.; Glupczynski, Y.; Wieler, L.H. Comparable high rates of extended-spectrum-beta-lactamase-producing Escherichia coli in birds of prey from Germany and Mongolia. PLoS ONE 2012, 7, e53039. [CrossRef]

63. Wheeler, E.; Hong, P.-Y.; Bedon, L.C.; Mackie, R.I. Carriage of antibiotic-resistant enteric bacteria varies among sites in Galapagos reptiles. J. Wildl. Dis. 2012, 48, 56-67. [CrossRef]

64. Islam, M.N. Prevalence and Antibiogram of E. coli and Salmonella spp. Isolates in Small Fruits Bat (Rousettus leschenaulti) and Associated Public Health Risk in Bangladesh. Ph.D. Thesis, Chittagong Veterinary and Animal Sciences University, Chittagong, Bangladesh, 2014.

65. Campbell, S. So long as it's near water: Variable roosting behaviour of the large-footed myotis (Myotis macropus). Aust. J. Zool. 2009, 57, 89-98. [CrossRef]

66. Ciechanowski, M. Community structure and activity of bats (Chiroptera) over different water bodies. Mamm. Biol. Z. Säugetierkund. 2002, 67, 276-285. [CrossRef]

67. Grindal, S.; Morissette, J.; Brigham, R. Concentration of bat activity in riparian habitats over an elevational gradient. Can. J. Zool. 1999, 77, 972-977. [CrossRef]

68. Vaughan, N.; Jones, G.; Harris, S. Habitat use by bats (Chiroptera) assessed by means of a broad-band acoustic method. J. Appl. Ecol. 1997, 34, 716-730. [CrossRef] 
69. Jackrel, S.L.; Matlack, R.S. Influence of surface area, water level and adjacent vegetation on bat use of artificial water sources. Am. Midl. Nat. 2010, 164, 74-80. [CrossRef]

70. Sirami, C.; Jacobs, D.S.; Cumming, G.S. Artificial wetlands and surrounding habitats provide important foraging habitat for bats in agricultural landscapes in the Western Cape, South Africa. Biol. Conserv. 2013, 164, 30-38. [CrossRef]

71. Amos, G.; Hawkey, P.; Gaze, W.; Wellington, E. Waste water effluent contributes to the dissemination of CTX-M-15 in the natural environment. J. Antimicrob. Chemother. 2014, 69, 1785-1791. [CrossRef]

72. Conte, D.; Palmeiro, J.K.; da Silva Nogueira, K.; de Lima, T.M.R.; Cardoso, M.A.; Pontarolo, R.; Pontes, F.L.D.; Dalla-Costa, L.M. Characterization of CTX-M enzymes, quinolone resistance determinants, and antimicrobial residues from hospital sewage, wastewater treatment plant, and river water. Ecotoxicol. Environ. Saf. 2017, 136, 62-69. [CrossRef]

73. Moremi, N.; Manda, E.V.; Falgenhauer, L.; Ghosh, H.; Imirzalioglu, C.; Matee, M.; Chakraborty, T.; Mshana, S.E. Predominance of CTX-M-15 among ESBL producers from environment and fish gut from the shores of Lake Victoria in Mwanza, Tanzania. Front. Microbiol. 2016, 7, 1862. [CrossRef]

74. Jenkins, R.K.; Racey, P.A. Bats as bushmeat in Madagascar. Madag. Conserv. Dev. 2008, 3. [CrossRef]

75. Kuzmin, I.V.; Bozick, B.; Guagliardo, S.A.; Kunkel, R.; Shak, J.R.; Tong, S.; Rupprecht, C.E. Bats, emerging infectious diseases, and the rabies paradigm revisited. Emerg. Health Threat. J. 2011, 4, 7159. [CrossRef] [PubMed]

(C) 2020 by the authors. Licensee MDPI, Basel, Switzerland. This article is an open access article distributed under the terms and conditions of the Creative Commons Attribution (CC BY) license (http://creativecommons.org/licenses/by/4.0/). 